\title{
The Influence of Gonadal Steroid Hormones on Immunoreactive Kisspeptin in the Preoptic Area and Arcuate Nucleus of Developing Agonadal Mice with a Genetic Disruption of Steroidogenic Factor 1
}

\author{
Tomaz Büdefeld ${ }^{a}$ Stuart A. Tobet ${ }^{c}$ Gregor Majdic ${ }^{a, b}$

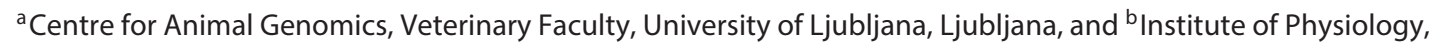 \\ Medical School, University of Maribor, Maribor, Slovenia; ' Department of Biomedical Sciences and School of Biomedical \\ Engineering, Colorado State University, Fort Collins, Colo., USA
}

\section{Key Words}

Kisspeptin · Sex difference · Brain · Estradiol · Genetic factor · Steroidogenic factor $1 \cdot$ SF-1 knockout mice

\begin{abstract}
Kisspeptin, a regulator of reproductive function and puberty in mammals, is expressed in the rostral (anteroventral) periventricular nucleus (AVPV) and arcuate nucleus ( $\operatorname{Arc}$ ), and its expression is at least partially regulated by estradiol in rodents. The aim of the present study was to determine contributions of genetic factors and gonadal steroid hormones to the sexual differentiation of kisspeptin-immunoreactive (kisspeptin-ir) cell populations in the AVPV and Arc during postnatal development using agonadal steroidogenic factor 1 (SF-1) knockout (KO) mice. To examine the effects of gonadal hormones on pubertal development of kisspeptin neurons, SF-1 KO mice were treated with estradiol benzoate (EB) from postnatal day (P)25 to P36, and their brains were examined at P36. No sex differences were observed in the SF-1 KO mice during postnatal development and after treatment with $E B$ - which failed to increase the number of kisspeptin-ir cells at P36 to the levels found in wild-type (WT) control females. This suggests that specific time periods of estradiol actions or other factors are needed for sexual dif-
\end{abstract}

\section{KARGER}

(c) 2015 S. Karger AG, Basel

0028-3835/15/1034-0248\$39.50/0

E-Mail karger@karger.com

www.karger.com/nen ferentiation of the pattern of immunoreactive kisspeptin in the AVPV. Kisspeptin immunoreactivity in the Arc was significantly higher in gonadally intact WT and SF-1 KO females than in male mice at $\mathrm{P} 36$ during puberty. Further, in WT and SF-1 KO females, but not in males, adult levels were reached at P36. This suggests that maturation of the kisspeptin system in the Arc differs between sexes and is regulated by gonad-independent mechanisms.

(c) 2015 S. Karger AG, Basel

\section{Introduction}

Kisspeptin (Kiss1) and its receptor, G protein-coupled receptor 54 (GPR54, Kiss1r), have been implicated in reproduction and sexual maturation as key regulators of gonadotropin-releasing hormone $(\mathrm{GnRH})$ secretion in mammals including humans [1-10]. The neuroanatomy of Kiss 1 -expressing neurons differs between mammalian species [11]. In the rodent brain, two populations of Kiss1expressing neurons reside in the rostral (anteroventral) periventricular nucleus (AVPV) and in the arcuate nucleus (Arc) of the hypothalamus [12-15]. Regulation of Kiss1 expression differs between these neural populations. In the AVPV, neurons expressing kisspeptin can be detected by 
immunohistochemistry (IHC) on postnatal day (P)10 in male and female mice [16]. Afterwards, the number of kisspeptin-immunoreactive (kisspeptin-ir) neurons progressively increases in a sex-specific manner until the onset of puberty, so that mature female mice have approximately 10 times more kisspeptin-ir neurons than males [16]. Several lines of evidence suggest the involvement of steroid hormones in the sexual differentiation of kisspeptin neurons. Colocalization studies showed that Kiss1-expressing neurons in the AVPV coexpress all major receptors for steroid hormones [estrogen receptor- $\alpha(E R \alpha)$ and $-\beta(E R \beta)$, androgen and progesterone receptors] $[12,17,18]$. Studies in rodents have shown that the sex-specific development of Kiss 1 neurons in the AVPV depends on both organizational and activational effects of gonadal steroid hormones. Treatment with androgens during the first postnatal week masculinized a number of Kiss 1 mRNA-expressing neurons in adult female rats $[15,19]$, and neonatal castration of male rats blocked masculinization of a number of kisspeptin-ir neurons [19], suggesting that a male phenotype is a consequence of permanent organizing actions of gonadal hormones on developing Kiss1 neurons in the AVPV. The development of the full female complement of kisspeptin-ir neurons in the AVPV in gonadectomized wildtype (WT) mice depends on the exposure to estrogens during puberty from P22 to P30 [20], although a study by Kim et al. [21] suggested that at the level of mRNA (but not peptide) expression, feminization of Kiss 1-expressing neurons might start earlier. In adulthood, Kiss 1 mRNA and kisspeptin expression in the AVPV depends on activational effects of gonadal steroids, as mRNA (in situ hybridization) and peptide (IHC) are decreased after gonadectomy and restored by estradiol replacement $[12,13,18,20]$. The effects of gonadal steroid hormones have been reinforced by studies with ERa knockout (KO) and aromatase $\mathrm{KO}$ (ARKO) mice [12, 13, 22, 23].

Kiss 1 mRNA and kisspeptin immunoreactivity in the Arc can be detected during early fetal development in mice and rats $[24,25]$, and it persists throughout prenatal and postnatal development [25-27]. Several sex differences in Kiss 1 mRNA and kisspeptin expression in the Arc in the developing brain have been reported in gonadally intact rodents. During embryonic development and in adulthood, sex differences in the mRNA content from dissected hypothalami and in the number of Kiss $1 \mathrm{mRNA}$ containing cells have been reported in mice [27]. Kiss 1 mRNA levels during neonatal, prepubertal and pubertal development [28] and in adulthood [14] have been reported to be higher in female than in male rats. Similarly, sex differences have been reported also at the peptide lev-

Kisspeptin Expression in the Brain in SF-1 KO Mice el from the neonatal period to adulthood in rats [26] and during early postnatal development from P10 to P25 in mice [23]. Previous studies have shown that gonadal steroid hormones regulate Kiss 1 mRNA levels and kisspeptin immunoreactivity in the Arc. Kiss 1 mRNA levels increased after gonadectomy and decreased by estradiol, testosterone and dihydrotestosterone replacement in mice and rats $[12-15,19]$. However, at the peptide level, decreased levels of immunoreactive kisspeptin following gonadectomy were restored with estradiol or dihydrotestosterone treatment in adult mice [23]. The requirement for estradiol to induce kisspeptin immunoreactivity in the Arc has also been suggested by studies in mice with ERa-ablated Kiss1 neurons [22] and in ARKO mice [23], both of which had diminished kisspeptin immunoreactivity during postnatal development. Similarly to kisspeptin neurons in the AVPV, neonatal exposure to estradiol benzoate (EB) significantly decreased kisspeptin immunoreactivity in the Arc in female rats [29].

Early studies demonstrated that central mechanisms regulating puberty onset are not gonad dependent [30, 31]. These observations have been confirmed by recent studies showing profound changes in Kiss 1 mRNA levels and kisspeptin immunoreactivity in constantly low peripheral estrogenic environments [26] or low levels of gonadal steroid hormones [32] as well as by RT-PCR, in situ hybridization and IHC studies showing that Kiss 1 expression in the Arc might be regulated by other factors such as members of the polycomb group protein family [33], neuropeptides [34-41], trophic factors [42] and neurotransmitters $[43,44]$. Despite the progress toward an identification of the gonad-independent factors involved in the regulation of Kiss 1 expression in the Arc during development in recent years, the role of these factors in the sexual differentiation of Kiss 1 expression in the Arc requires further clarification.

Gonadal steroid hormones and genes on sex chromosomes are two major factors influencing brain sexual differentiation in mammals [45-47]. Two genetic mouse models have provided a better understanding of contributions of sex chromosomes to brain sexual differentiation and function, namely the 'four core genotype' model [48-51] and mice with disruption of the steroidogenic factor 1 (Nr5a1) gene (SF-1 KO) [52, 53]. In SF-1 KO mice, genital ridges disintegrate early during embryonic development [54], before the initiation of steroidogenesis in fetal testes [55]. Therefore, these mice are not exposed to endogenous gonadal steroid hormones and, when compared to hormonally manipulated WT control mice, they represent a unique model for studying genetic and 
hormonal influences on brain sexual development separately [47].

The aim of the present study was to determine whether there are any sex differences in the production of immunoreactive kisspeptin in the AVPV and Arc after birth in agonadal SF-1 KO mice either without hormones or after treatment with estradiol. In addition, it was our goal to determine if a peripubertal window of estradiol exposure from P25 to P36 for the development of kisspeptin immunoreactivity is sufficient to induce normal levels of immunoreactive kisspeptin in agonadal SF-1 KO mice in the AVPV area.

\section{Materials and Methods}

Animals and Brain Recovery

Heterozygous mice with a disrupted $s f-1$ (Nr5a1) allele (SF$1^{+/-}$) were backcrossed for more than 10 generations to C57BL/6 J mice to produce a congenic line. All mice were housed under standard laboratory conditions at the University of Ljubljana Veterinary Faculty in a 12:12-hour light/dark cycle (lights off at 18:00 h) with a phytoestrogen-free diet (No. 2916; Harlan Teklad, Milan, Italy) and water ad libitum. All animal experiments were conducted according to ethics principles and in accordance with the EU directive $(2010 / 63 / \mathrm{EU})$. The experiments were approved by the Veterinary Commission of Slovenia and the Animal Care and Use Committee at Colorado State University.

SF- $1^{+/-}$mice were mated to produce homozygous SF-1 KO and control WT offspring. Due to a lack of gonads during fetal development, SF-1 KO mice develop female reproductive organs and external genitalia regardless of genetic sex. In the present study, SF-1 KO mice were sexed according to their chromosomal sex, i.e. $\mathrm{XY}=\mathrm{SF}-1 \mathrm{KO}$ males and $\mathrm{XX}=\mathrm{SF}-1 \mathrm{KO}$ females. To ensure survival of SF-1 KO mice, all newborn pups were injected subcutaneously daily for 6-7 days with $50 \mu \mathrm{l}$ of a corticosteroid cocktail in corn oil $(400 \mu \mathrm{g} / \mathrm{ml}$ hydrocortisone, $400 \mathrm{ng} / \mathrm{ml}$ dexamethasone and $500 \mathrm{ng} / \mathrm{ml}$ fludrocortisone acetate; all from Sigma, Steinheim, Germany). The mice were genotyped by PCR assay of tail DNA on day 6 or 7 after birth as previously described [56]. Female WT littermates or female pups from other C57BL/6J litters born within 3 days were used as a source of adrenal transplants; these techniques have been reported previously [57]. After adrenal transplantation, SF-1 KO mice received 3 more corticosteroid injections on days 9,12 and 16 until weaning on P21. WT mice used for controls were subjected to the same corticosteroid treatment protocol as were SF-1 KO mice. After weaning, mice of the same chromosomal sex were group housed (2-3 per cage) until the time of sacrifice (gonadectomized WT and SF-1 KO mice were never housed with the gonadally intact WT mice, due to the possible aggressive behavior of WT males).

Some WT mice were gonadectomized before puberty (P21) to prepare controls with a gonadal status comparable to that of SF-1 KO mice. For gonadectomies, WT mice were anesthetized with a mixture of ketamine [Vetoquinol Biowet, Gorzów Wielkopolski, Poland; $100 \mu \mathrm{g} / \mathrm{g}$ body weight (BW)], xylazine (Chanelle Pharmaceuticals Ltd., Loughrea, Ireland; $10 \mu \mathrm{g} / \mathrm{g}$ BW) and acepromazine
(Fort Dodge Animal Health, Fort Dodge, Iowa, USA; $2 \mu \mathrm{g} / \mathrm{g}$ BW), and ovaries and testes were removed through a single or bilateral incision, respectively. After gonadectomy, the mice received 2 injections of the analgesic butorphanol (Fort Dodge Animal Health; $1.7 \mu \mathrm{g} / \mathrm{g} \mathrm{BW}$ ). To control for gonadectomy, gonadally intact WT and SF-1 KO mice were sham operated at P21.

To study the effect of EB exposure during a pubertal time period, SF-1 KO and gonadectomized WT mice were anesthetized with a mixture of ketamine, xylazine and acepromazine and implanted subcutaneously with Silastic capsules [1.02 $\mathrm{mm}$ i.d. $\times 2.16$ mm o.d.; Dow Corning, Midland, Mich., USA; $5 \mathrm{~mm}$ of tubing filled with EB (Sigma) and cholesterol (Sigma) at a ratio of 1:1] for the period from P25 to P36 as reported previously [58].

At the time of sacrifice, the mice were anesthetized as described above and perfused with $4 \%$ paraformaldehyde (Sigma) in $0.1 \mathrm{M}$ phosphate buffer $(\mathrm{pH}=7.4)$. All adult, gonadally intact WT females were sacrificed in diestrus, based on vaginal smear cytology. After removal, the brains remained in the same fixative overnight at $4^{\circ} \mathrm{C}$ and were then stored until immunocytochemical processing in $0.1 \mathrm{M}$ phosphate buffer at $4^{\circ} \mathrm{C}$.

Puberty was determined by monitoring vaginal opening in a separate cohort of 10 female WT and SF-1 ${ }^{+/-}$mice. The time of vaginal opening ranged from P34 to P38, with most female mice in the colony presenting with vaginal opening by P36.

\section{Experimental Design}

To study the effects of sex chromosomes and gonadal steroids on kisspeptin sexual differentiation in the brain, SF-1 KO mice $(M: n=18 ; F: n=19)$ were compared to gonadally intact $(M: n=19$; $\mathrm{F}: \mathrm{n}=18)$ or gonadectomized $(\mathrm{M}: \mathrm{n}=9 ; \mathrm{F}: \mathrm{n}=10)$ control WT mice at three different stages of development: before puberty at P25, approximately during puberty at P36 and in young adulthood at P60. The effect of EB on kisspeptin brain sexual differentiation was studied in gonadectomized WT mice $(\mathrm{M}: \mathrm{n}=5 ; \mathrm{F}: \mathrm{n}=6)$ and SF-1 KO mice $(M: n=6 ; F: n=5)$ that were implanted with EB Silastic capsules from P25 to P36 (during a pubertal period) and sacrificed at P36.

\section{IHC on Floating Brain Sections}

Brains were embedded in 5\% agarose (Sigma) and sectioned at $50 \mu \mathrm{m}$ in cold $0.05 \mathrm{M}$ PBS using a vibrating microtome (Integraslice 7550 MM; Campden Instruments, Loughborough, UK). Sections were placed in alternating containers to aid free-floating tissue processing and to help track locations more readily. Before primary antibodies, sections were incubated in $0.1 \mathrm{M}$ glycine (Sigma) and $0.5 \%$ sodium borohydride (Sigma) in $0.05 \mathrm{M}$ PBS for $30 \mathrm{~min}$ and $15 \mathrm{~min}$ at $4{ }^{\circ} \mathrm{C}$, respectively. They were then blocked in $5 \%$ normal goat serum (Chemicon, Temecula, Calif., USA) containing $0.5 \%$ Triton X-100 (Sigma) and $1 \% \mathrm{H}_{2} \mathrm{O}_{2}$ (Merck, Darmstadt, Germany) for $30 \mathrm{~min}$ at $4^{\circ} \mathrm{C}$. Sections were incubated in rabbit primary antiserum against kisspeptin 10 (gift from Dr. A. Caraty; this antiserum has been used and validated before [16]) diluted $1: 30,000$ in $0.05 \mathrm{M}$ PBS containing $1 \%$ bovine serum albumin (Sig$\mathrm{ma}$ ) and $0.5 \%$ Triton $\mathrm{X}-100$ over 3 nights at $4^{\circ} \mathrm{C}$ with shaking. They were then washed in $0.05 \mathrm{M}$ PBS containing $1 \%$ normal goat serum and $0.02 \%$ Triton X-100 four times $15 \mathrm{~min}$ at room temperature. Biotinylated secondary antibodies (Jackson ImmunoResearch, West Grove, Pa., USA) against primary rabbit antisera were diluted 1:500 in $0.05 \mathrm{M}$ PBS containing 1\% normal goat serum and $0.5 \%$ Triton X-100. Sections were incubated with secondary anti- 
bodies for $2 \mathrm{~h}$, followed by 4 washes ( 15 min each) in $0.05 \mathrm{M} \mathrm{PBS}$ buffer containing $0.02 \%$ Triton X-100. Streptavidin-horseradish peroxidase complex (Jackson ImmunoResearch) was diluted $1: 2,500$ in $0.05 \mathrm{M}$ PBS solution containing $0.5 \%$ Triton X-100. Sections were incubated with streptavidin-conjugated horseradish peroxidase for $1 \mathrm{~h}$ at room temperature and then washed in Trisbuffered saline (0.05 M Tris- $\mathrm{HCl} / 0.9 \% \mathrm{NaCl}$; pH 7.5; Sigma) for $1 \mathrm{~h}$ at room temperature. Antigen-antibody complexes were visualized as a black reaction product by incubating sections in $0.025 \%$ 3,3'-diaminobenzidine/ammonium nickel(II) sulfate substrate (Sigma) in Tris-buffered saline ( $\mathrm{pH}$ 7.5) containing $0.02 \% \mathrm{H}_{2} \mathrm{O}_{2}$ for $5 \mathrm{~min}$ at room temperature. After mounting on slides, sections were dried and coverslipped using hydrophobic medium (Pertex, Burgdorf, Germany). Immunocytochemical controls were based on omitting the primary antibodies from control sections and on a validation of immunoreactivity with patterns of distribution from a prior report [16].

Data Collection and Analyses

Digital images of the AVPV and Arc were obtained using a Nikon Eclipse 80i microscope with a Nikon DS-Fil camera. Kisspeptin-ir cells in the AVPV were counted directly under the microscope in coronal sections considered in order from rostral to caudal on the microscopic slides. Cells were counted on both the left and the right side of the AVPV on two sections that always corresponded to sections approximately 0.14 and $0.26 \mathrm{~mm}$ rostral to bregma according to stereotaxic coordinates [59]. Kisspeptin immunoreactivity on both the left and the right side of the Arc was quantified in coronal sections $(\times 100$ magnification; the third ventricle and base of the brain served as reference boundaries) corresponding to sections approximately $1.7 \mathrm{~mm}$ caudal to bregma according to stereotaxic coordinates [59] using a custom software (Surfkvad; made by Dr. Marko Kreft, Institute of Pathophysiology, Faculty of Medicine, University of Ljubljana). For the purpose of analysis with Surfkvad, all digital images were taken with the same illumination settings and prepared accordingly using the Adobe Photoshop software package (version 8.0) as follows: digital images were standardized for illumination, which eliminated possible differences in intensity of the background between images, were converted to grayscale and were then subjected to threshold conversion in order to selectively identify immunoreactive elements with the threshold limit set to 50\%. Black-and-white images were then analyzed with Surfkvad software, which calculates the percentage of dark area (immunoreactivity) in a boxed area of interest $(940 \times 970 \mu \mathrm{m})$ bounded by the third ventricle medially and the base of the brain.

\section{Statistical Analysis}

Statistical analysis was performed using the NCSS software package (NCSS 2007; NCSS, Kaysville, Utah, USA). Statistical differences in the number of kisspeptin-ir cells in the AVPV and the kisspeptin-ir area in the Arc between gonadally intact WT mice, gonadectomized WT mice and SF-1 KO mice were examined by three-factor ANOVA with sex, genotype/gonadal status and age as independent factors. Differences in the number of kisspeptin-ir cells in the AVPV between different stages of development in gonadally intact male and female WT mice were examined in a planned comparison by two-factor ANOVA with sex and age as independent factors. Differences in the kisspeptin-ir area between different developmental stages in gonadally intact WT and SF-1 $\mathrm{KO}$ mice were examined in a planned comparison with sex, geno-

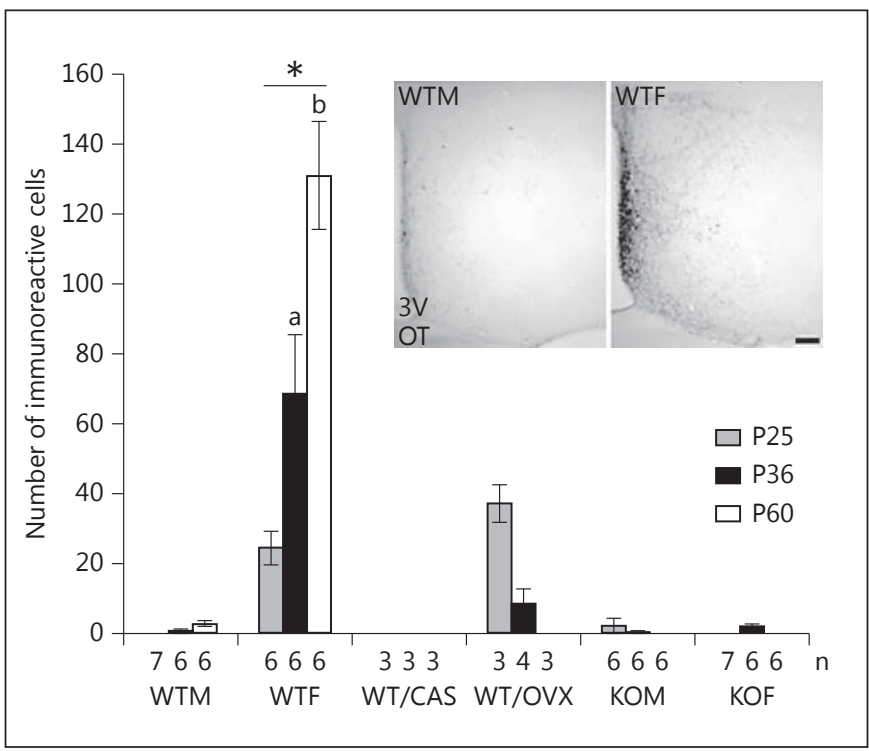

Fig. 1. The digital inset image shows representative sections with kisspeptin-ir cells in the AVPV at P60 in WT male (WTM) and WT female (WTF) mice. The graph illustrates the number of kisspeptin-ir cells in the AVPV in gonadally intact WTM and WTF mice, WT/CAS and WT/OVX mice (gonadectomized at P21) and agonadal SF-1 KO male (KOM) and female (KOF) mice in three different developmental stages: at P25 (before puberty), at P36 (during puberty) and at P60 (in adulthood). Numbers of cells are presented as means \pm SEM. ${ }^{*} \mathrm{p}<0.05$ (different from WTM, WT/ CAS, WT/OVX, KOM and KOF mice); ${ }^{a} \mathrm{p}<0.05$ (different from WTF mice at P25); ${ }^{b} \mathrm{p}<0.05$ (different from WTF mice at P36). $3 \mathrm{~V}=$ Third ventricle; OT $=$ optic tract. Scale bar $=100 \mu \mathrm{m}$.

type and age as independent factors. Differences in the kisspeptinir area between gonadally intact WT, gonadectomized WT and SF-1 KO mice at P36 only were examined in a planned comparison by three-factor ANOVA with sex, genotype and gonadal status as independent factors. The effect of EB on the number of kisspeptinir cells in the AVPV and the kisspeptin-ir area in the Arc was examined in the 36-day-old mice only by three-factor ANOVA with genotype/gonadal status, sex and treatment as independent factors. When applicable, Fisher's least significant difference (LSD) post hoc analyses were used to determine statistical differences between groups. Statistical differences were considered significant at $\mathrm{p}<0.05$. All data are presented as means \pm SEM.

\section{Results}

\section{Lack of SF-1 Did Not Result in WT Female Levels of Kisspeptin-ir Cells in the AVPV in the Absence of Gonadal Steroids}

As expected, kisspeptin-ir cells in the AVPV were detected in the periventricular area (fig. 1). The number of kisspeptin-ir cells in the AVPV increased with age from 


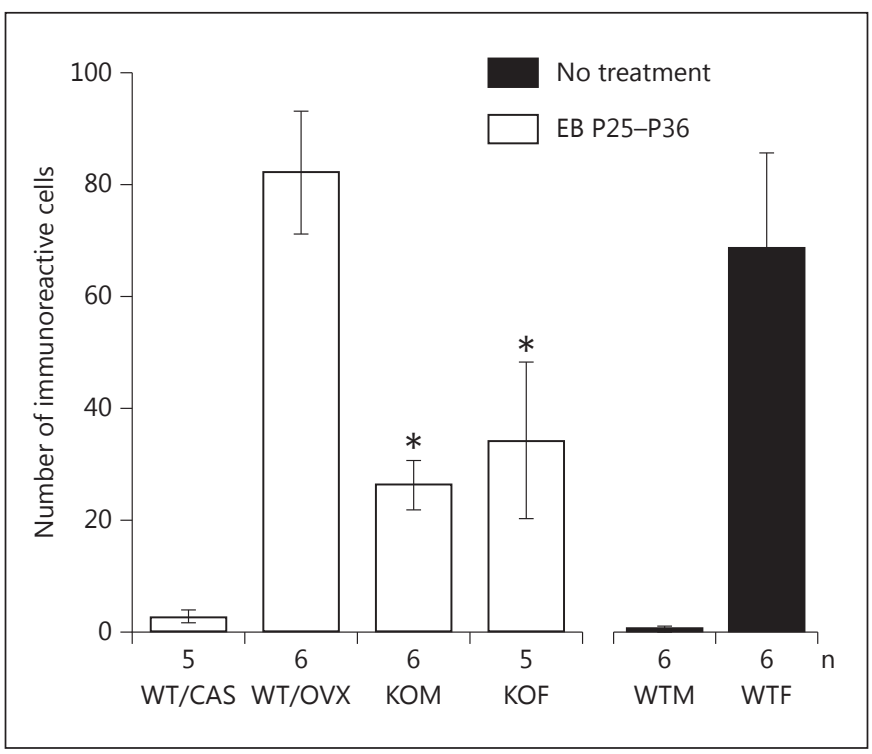

Fig. 2. The graph illustrates the number of kisspeptin-ir cells in the AVPV from 36-day-old, gonadally intact WT male (WTM) and female (WTF) mice (same bars as in fig. 1, included for comparison), WT/CAS and WT/OVX mice (gonadectomized at P21) and SF-1 KO male (KOM) and female (KOF) mice. Gonadectomized mice and agonadal SF-1 KO mice were treated with EB from P25 to P36. Treatment restored the number of kisspeptin-ir cells in WT/OVX mice to the levels seen in WTF mice, while the number of kisspeptin-ir cells in agonadal SF-1 KO mice of both sexes was significantly lower $(\mathrm{p}<0.05)$ in comparison to that in WTF mice even after EB treatment. Numbers of cells are presented as means \pm SEM. ${ }^{*} \mathrm{p}<0.05$ (lower than in EB-treated WT/OVX and untreated WTF mice).

$\mathrm{P} 25$ to $\mathrm{P} 60$ and reached a maximum at $\mathrm{P} 60[\mathrm{~F}(4,103)=$ 25.73; $\mathrm{p}<0.001$, Fisher's LSD; $\mathrm{p}<0.05]$ in gonadally intact male and female WT mice in a sex-specific manner $[\mathrm{F}(2,103)=81.61 ; \mathrm{p}<0.001$, Fisher's LSD; $\mathrm{p}<0.05]$. Furthermore, a planned comparison showed that the number of kisspeptin-ir cells significantly $[\mathrm{F}(2,35)=17.68$; $\mathrm{p}<0.001$, Fisher's LSD; $\mathrm{p}<0.05$ ] increased from P25 to P36 and from P36 to P60 in gonadally intact WT females but not males, which led to higher $[\mathrm{F}(2,35)=17.68$; $\mathrm{p}<$ 0.001 , Fisher's LSD; $\mathrm{p}<0.05$ ] kisspeptin-ir cell numbers in WT females than in WT males at P25, P36 and P60. Gonadectomy in WT mice before puberty at P21 led to significantly reduced numbers of kisspeptin-ir cells in males (WT/CAS) and females (WT/OVX) in comparison to gonadally intact WT mice $[\mathrm{F}(2,103)=81.61 ; \mathrm{p}<0.001$, Fisher's LSD; $\mathrm{p}<0.05)$. In gonadectomized WT mice, a sex difference in the number of kisspeptin-ir cells was conserved at P25 ( $p<0.05$, Fisher's LSD), but not at P36 and P60, when kisspeptin-ir cells were not detected in this area in either sex. In agonadal SF-1 KO mice, the total number of kisspeptin-ir cells was indistinguishable ( $\mathrm{p}>$ 0.05 , Fisher's LSD) from that in gonadally intact/gonadectomized WT males regardless of sex at all three ages studied (fig. 1), and it did not differ ( $\mathrm{p}>0.05$, Fisher's LSD) from that in WT/OVX females at P60.

\section{Lack of SF-1 Did Not Result in Female Levels of}

Kisspeptin-ir Cells in the AVPV in the Presence of

\section{Gonadal Steroids}

To examine the effect of exposure to EB on the number of kisspeptin-ir cells in the AVPV during puberty, gonadectomized WT and agonadal SF-1 KO mice were exposed to EB from P25 to P36. EB treatment increased $[\mathrm{F}(1,55)=23.29 ; \mathrm{p}<0.001]$ the total number of kisspeptin-ir cells in both gonadectomized WT and SF-1 KO mice. A significant interaction [sex $\times$ genotype/gonadal status $\times$ treatment; $F(2,55)=4.37 ; \mathrm{p}<0.05$ ] suggests that EB treatment from P25 to P36 restored the total number of kisspeptin-ir cells to WT female levels only in WT/ OVX mice, but surprisingly not in male and female agonadal EB-treated SF-1 KO mice, which had significantly fewer $[F(2,55)=20.86 ; p<0.001$, Fisher's LSD; $p<0.05]$ kisspeptin-ir cells compared to EB-treated WT/OVX and untreated, gonadally intact female WT mice (fig. 2).

\section{Lack of SF-1 Did Not Prevent Sexually Dimorphic}

Kisspeptin Immunoreactivity in the Arc at the Time of

Puberty Onset in the Absence of Gonadal Steroids

The kisspeptin-ir area in the Arc increased with age from $\mathrm{P} 25$ to $\mathrm{P} 60$, reaching a maximum at $\mathrm{P} 60[\mathrm{~F}(4,92)=$ 7.97; $\mathrm{p}<0.001$, Fisher's LSD; $\mathrm{p}<0.05$ ], in gonadally intact WT mice in a sex-specific manner $[\mathrm{F}(2,92)=23.51$; $\mathrm{p}<$ 0.001 , Fisher's LSD; $p<0.05$, with gonadally intact WT females having a significantly greater immunoreactive area than males at all three ages studied $[\mathrm{F}(4,92)=3.09$; $\mathrm{p}<0.05$, Fisher's LSD; $\mathrm{p}<0.05]$. Overall, gonadectomy at P21 significantly decreased $[F(2,92)=26.87 ; \mathrm{p}<0.001]$ the kisspeptin-ir area in comparison to gonadally intact WT mice in a sex-dependent manner, with WT/OVX mice having a significantly greater $[\mathrm{F}(2,92)=23.51$; $\mathrm{p}<$ 0.001 , Fisher's LSD; $\mathrm{p}<0.05$ ] kisspeptin-ir area than WT/ CAS mice (fig. 3).

The kisspeptin-ir area in the Arc was smaller in male and female SF-1 KO mice than in gonadally intact female $\mathrm{WT}$ and WT/OVX mice $[\mathrm{F}(2,92)=23.51 ; \mathrm{p}<0.001$, Fisher's LSD; $p<0.05$ ] at all ages studied (fig. 3), and this was due to the substantial increase observed at P25 in WT/ OVX mice, which may reflect increased kisspeptin immunoreactivity after gonadectomy, as reported previous- 

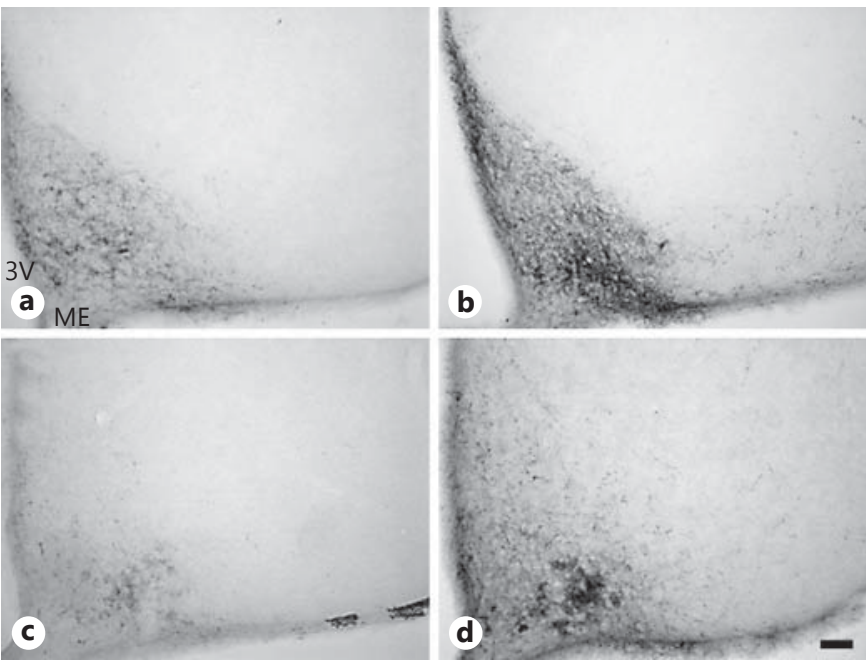

Fig. 3. a-d Representative images of kisspeptin immunoreactivity in the Arc at P36 in gonadally intact WT male (WTM; a) and female (WTF; b) as well as in agonadal SF-1 KO male (KOM; c) and female (KOF; d) mice. Gonadally intact WTF and agonadal KOF mice had a significantly greater kisspeptin-ir area in the Arc during puberty at P36 than gonadally intact WTM and agonadal KOM mice, respectively. e The graph illustrates the kisspeptin-ir area in the Arc in gonadally intact WTM and WTF mice, WT/CAS and WT/OVX mice (gonadectomized at P21) and agonadal KOM and KOF mice in three different developmental stages: at P25 (before

ly [12]. Later, at P36 and P60, the kisspeptin-ir area in WT/OVX mice was within the range of immunoreactivity found in agonadal SF-1 KO mice. However, female agonadal SF-1 KO mice had a significantly greater immunoreactive area in the Arc than WT/CAS mice $[\mathrm{F}(2,92)=$ 23.51; $\mathrm{p}<0.001$, Fisher's LSD; $\mathrm{p}<0.05$ ] (fig. 3).

Interestingly, the kisspeptin-ir area in gonadally intact WT females and SF-1 KO females reached adult levels already at P36, while in gonadally intact WT males and SF-1 KO males, the immunoreactive area at P36 was smaller ( $\mathrm{p}<0.05$; Fisher's LSD) than that at P60 (fig. 3). This suggests a later maturation of immunoreactive kisspeptin levels in gonadally intact WT and SF-1 KO males in comparison to females, and this is likely regulated by gonadindependent factors, as it is conserved in SF-1 KO mice.

\section{Sexually Dimorphic Kisspeptin Immunoreactivity in} the Arc Was Eliminated in the Presence of Sex Steroid Hormones in Mice Lacking SF-1

To examine the effect of sex steroid hormones on immunoreactive kisspeptin levels after gonadectomy, WT

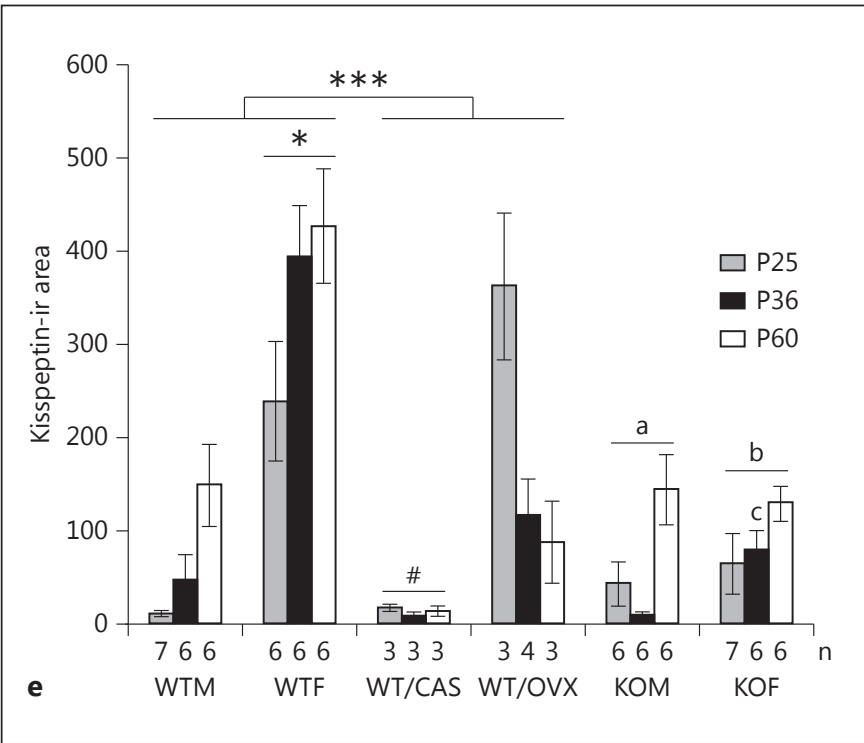

puberty), at P36 (during puberty) and at P60 (in adulthood). The kisspeptin-ir area is presented as the mean \pm SEM. ${ }^{*} \mathrm{p}<0.05$ (different from WTM, WT/CAS, WT/OVX and SF-1 KO mice over all ages studied); ${ }^{* * *} \mathrm{p}<0.001$ (higher immunoreactivity in WT than in gonadectomized WT mice); ${ }^{\#} \mathrm{p}<0.05$ (different from WT/OVX mice); ${ }^{\mathrm{a}} \mathrm{p}<0.05$ (different from WTF and WT/OVX mice); ${ }^{\mathrm{b}} \mathrm{p}<$ 0.05 (different from WTF, WT/OVX and WT/CAS mice); ${ }^{c} \mathrm{p}<$ 0.05 (higher immunoreactivity than in $\mathrm{KOM}$ mice at P36). $3 \mathrm{~V}=$ Third ventricle; $\mathrm{ME}=$ median eminence. Scale bar $=100 \mu \mathrm{m}$.

mice gonadectomized at $\mathrm{P} 21$ and SF-1 $\mathrm{KO}$ mice were treated with EB from P25 to P36 and examined at P36. An analysis did not reveal any statistically significant effect of EB treatment on the kisspeptin-ir area, although, interestingly, slight increases in immunoexpression in SF-1 $\mathrm{KO}$ males and slight decreases in kisspeptin immunoexpression in SF-1 KO females, respectively, eliminated the sex difference observed in hormonally naïve SF-1 KO mice at P36 (fig. 4). In gonadectomized WT mice, the kisspeptin-ir area remained greater $[\mathrm{F}(1,52)=44.08$; $\mathrm{p}<$ 0.001 , Fisher's LSD; $\mathrm{p}<0.05$ ] in females than in males.

\section{Discussion}

Neurons expressing the Kiss 1 gene and its receptor have a major role in the regulation of $\mathrm{GnRH}$ release in the hypothalamus and in the onset of puberty, as evidenced by studies in mice $[2,9,60]$ and humans $[1,3]$. In the murine brain, expression of Kiss 1 is sex dependent, and this sex difference is usually considered a result of exposure to 


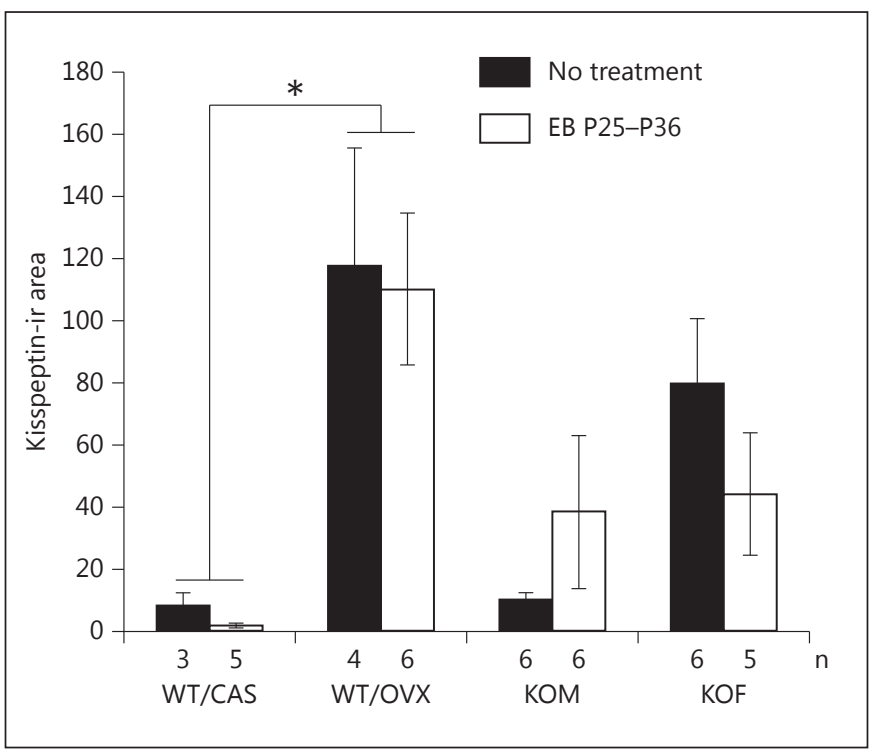

Fig. 4. The graph illustrates the kisspeptin-ir area in the Arc from 36-day-old WT/CAS and WT/OVX mice gonadectomized at P21 and SF-1 KO male (KOM) and female (KOF) mice. All mice were either untreated or treated with EB from P25 to P36. EB treatment from P25 to P36 had no effect on the kisspeptin-ir area in both WT/CAS and WT/OVX mice when compared to untreated gonadectomized WT mice. However, EB treatment did eliminate the sex difference in agonadal SF-1 KO mice at P36 by moderately (nonsignificantly) increasing immunoexpression in males and decreasing immunoexpression in females. The kisspeptin-ir area is presented as the mean \pm SEM. ${ }^{*} \mathrm{p}<0.05$ (higher immunoreactivity in WT/OVX than WT/CAS mice).

sex steroid hormones, especially neonatally in male rats [15], but also prenatally in mice [27]. Previous studies have suggested that the numbers of Kiss 1 mRNA-expressing [61] and kisspeptin-ir neurons [20] reach adult levels by the time of puberty and that EB treatment before/during puberty is sufficient for the full restoration of these levels in the AVPV in WT/OVX mice [20].

In the present study, the kisspeptin-ir neural population in the AVPV was therefore examined in agonadal SF-1 KO mice during postnatal development and after treatment with EB during the pubertal period. If perinatal gonadal steroids are sufficient to cause a masculine pattern of kisspeptin expression in adult mice, then in agonadal SF-1 KO mice (regardless of genetic sex) kisspeptin immunoreactivity should follow a female pattern of expression after treatment with EB. The results of the current study, however, show a diminished number of cells containing immunoreactive kisspeptin in untreated agonadal SF-1 KO mice from P25 to early adulthood. Treat- ment of WT/OVX mice with EB from P25 to P36 restored the number of kisspeptin-ir cells to the levels found in gonadally intact female WT mice at P36 in the AVPV. In contrast, similar treatment of SF-1 KO mice of both sexes did not produce similar numbers of kisspeptin-ir cells.

An analysis of the significant interaction between genotype/gonadal status, sex and treatment suggests that treatment from P25 until P36 was not sufficient for full induction of immunoreactive kisspeptin in cells in the AVPV in SF-1 KO mice, and that either earlier programming of this response or some other factor(s) besides estradiol is needed for full induction of immunoreactive kisspeptin in the AVPV. Such programming could be caused by earlier exposure to gonadal steroid hormones or some other gonadal factors that are absent in SF-1 KO mice due to early gonadal agenesis. These results are similar in part to results from mice lacking the aromatase enzyme (ARKO mice) [23]. In that study, postnatal or adult treatment with EB induced expression of kisspeptin in the hypothalamus of male and female ARKO mice (that normally express very low levels of kisspeptin), but the number of cells in ARKO mice was lower than in WT mice even after treatment with EB, suggesting an earlier organizational period, probably dependent on ovarian steroid hormones [23]. In agreement, another report [21] indicated that exposure to estradiol during an earlier juvenile period - and not just during puberty, as suggested in some previous studies [20] - is likely needed for full feminization of the kisspeptin system in the AVPV region. Taken together, it seems likely that there are additional factors, perhaps an early exposure to low levels of ovary-derived estrogens between P10 and P15, that are indispensable for the development of Kiss 1 neurons in the AVPV in female mice, and possibly some other femalespecific factors [23, 62-64].

In the present study, immunoreactive kisspeptin in Arc fibers was followed from before puberty (P25) to after puberty (P60) in gonadally intact/gonadectomized WT and agonadal SF-1 KO mice. Previous studies have shown that besides gonadal steroid hormones [12-15, 19, 23], Kiss 1 expression at the mRNA and peptide level in the Arc is also regulated by various biological molecules including neuropeptides (dynorphin A [34], neurokinin B [35] and prolactin [37]), neurotransmitters (GABA and glutamate $[43,44]$ ), trophic factors (LRH-1 [42], insulin [38] and mTOR signaling [39]), and metabolic factors (leptin [36], ghrelin [41] and neuropeptide Y [40]). Further, functional changes in Kiss 1 mRNA expression in the Arc associated with puberty control independent of gonadal hormones were reported to depend on the poly- 
comb group of transcriptional silencers [33]. The kisspeptin-ir area in adult, gonadally intact WT mice was established through a gradual increase starting from P25 in both male and female WT mice, with females having a greater immunoreactive area than males at all ages studied. The kisspeptin-ir area in the Arc in agonadal SF-1 KO mice did not differ between sexes at P25 and P60, but there was a significant difference between SF-1 KO males and females during puberty at P36. While gonadectomy decreased kisspeptin immunoreactivity in the Arc in both males and females in comparison to gonadally intact WT mice, it did not eliminate the sex differences in the kisspeptin-ir area. Similarly as in intact WT mice, gonadectomized WT females had a significantly greater kisspeptin-ir area than gonadectomized WT males at all ages studied. These results suggest that sexual differentiation of the kisspeptin system in the Arc during postnatal development in mice depends on gonadal hormone-dependent factors. However, our results also suggest that sexual differentiation of the kisspeptin system during puberty differs between males and females, and this depends on additional regulatory mechanisms provided by gonadindependent factors, as has been observed in agonadal SF-1 KO mice.

Functional reactivation of GnRH neurons and consequent activation of the hypothalamic-pituitary-gonadal axis represents a hallmark of the beginning of puberty that occurs earlier in girls than in boys. In spite of dealing with the regulation of gonadal hormone synthesis and the almost complete dependence of Kiss $1 \mathrm{mRNA}$ and kisspeptin expression on gonadal hormones, it is interesting that some changes in gene expression controlling GnRH neuron activity occur independently of circulating gonadal levels. For example, increases in Kiss 1 mRNA expression in the Arc during puberty occur in male mice gonadectomized at P14 [65] and in male and female hypogonadal $(h p g)$ mice [32]. Observations in rats that the hypothalamic-pituitary-gonadal axis becomes responsive to kisspeptin-54 at P30 and not earlier [66] further suggest a regulation of $\mathrm{GnRH}$ neuron reactivation by intrinsic biological clocks. The current study extends these observations by showing sexspecific increases in the kisspeptin-ir area in the Arc during puberty in agonadal SF-1 KO mice. At the time of puberty, female agonadal SF-1 KO mice had a significantly greater area containing kisspeptin immunoreactivity than male agonadal SF-1 KO mice. The levels of immunoreactive kisspeptin were maximal in female agonadal SF-1 KO mice already at P36, while there was a significant increase between days 36 and 60 in SF-1

Kisspeptin Expression in the Brain in SF-1 KO Mice
KO males, suggesting that males reach the adult pattern of expression later than females, possibly due to later pubertal development. Despite the differences in the total area of kisspeptin immunoreactivity between agonadal SF-1 KO and gonadally intact WT mice, developmental dynamics in the area of kisspeptin immunoreactivity similar to those in agonadal SF-1 KO mice were observed in gonadally intact WT mice. The results of the current study suggest that sexually dimorphic timing in changes in the area of kisspeptin immunoreactivity during puberty is regulated by gonad-independent factors.

Sex differences in kisspeptin expression in the Arc during early postnatal development in mice to some extent depend on gonadal hormones [23]. In the current study, gonadectomy before puberty at P21 decreased but did not eliminate kisspeptin immunoreactivity in male and female WT mice later during puberty (at P36) and in early adulthood (at P60) in a sex-specific manner. However, treatment with EB during puberty from P25 to P36 did not restore the kisspeptin-ir area in gonadectomized WT mice to the levels in gonadally intact WT mice, suggesting that other gonadal hormones (perhaps testosterone in males [13] and progesterone in females) and/or other as yet unknown factors regulate the levels of immunoreactive kisspeptin during puberty in the Arc. This is in contrast to the results of a study in ARKO mice that reported a complete restoration of kisspeptin immunoreactivity in the Arc in adult WT and ARKO mice after 10 days of treatment with estradiol or dihydrotestosterone [23]. However, the mice in that study were left gonadally intact during puberty and gonadectomized only in adulthood, which might have impacted the Arc Kiss 1 circuitry differently than prepubertal gonadectomy. Furthermore, the mice in the present study were not treated with colchicine before sacrifice, which is why the effect of EB on the increased kisspeptin-ir area could be masked by an increased kisspeptin transport and secretion. Kisspeptin expression in the Arc was studied by IHC, which did not allow us to determine whether there were other factors regulating the amount of immunoreactive kisspeptin in fibers. Therefore, the current data (area of kisspeptin immunoreactivity) only provide information about the quantity of immunoreactive kisspeptin in fibers in the Arc at the time of sacrifice.

In conclusion, the results of the current study show that EB treatment from P25 to P36 could not restore the number of kisspeptin-ir cells in the AVPV in agonadal SF-1 KO mice to numbers found in gonadally intact WT 
or EB-treated WT/OVX females. This suggests that either earlier programming by sex steroids (before P21) is needed for a normal expression of kisspeptin in the AVPV or other factor(s) besides estradiol, either at puberty or during earlier development, are needed for the capacity to express kisspeptin in the AVPV. Furthermore, results from the Arc analyses suggest that maturation of immunoreactive kisspeptin in the Arc occurs at different ages in males and females, and this sex difference is independent of gonads, since it was also observed in agonadal SF-1 KO mice.

\section{Acknowledgements}

We would like to thank Dr. Alain Caraty for contributing kisspeptin antibodies and Ms. Nina Sterman for animal husbandry and technical assistance. This study was supported by NIH R01 MH61376 (to S.A.T. and G.M.) and ARRS P4-0053 (to G.M. and T.B.).

\section{References}

$>1$ de Roux N, Genin E, Carel JC, Matsuda F, Chaussain JL, Milgrom E: Hypogonadotropic hypogonadism due to loss of function of the KiSS1-derived peptide receptor GPR54. Proc Natl Acad Sci USA 2003;100:10972-10976.

-2 Funes S, Hedrick JA, Vassileva G, Markowitz L, Abbondanzo S, Golovko A, Yang S, Monsma FJ, Gustafson EL: The KiSS-1 receptor GPR54 is essential for the development of the murine reproductive system. Biochem Biophys Res Commun 2003;312:1357-1363.

$>3$ Seminara SB, Messager S, Chatzidaki EE, Thresher RR, Acierno JS Jr, Shagoury JK, BoAbbas Y, Kuohung W, Schwinof KM, Hendrick AG, Zahn D, Dixon J, Kaiser UB, Slaugenhaupt SA, Gusella JF, O'Rahilly S, Carlton MB, Crowley WF Jr, Aparicio SA, Colledge WH: The GPR54 gene as a regulator of puberty. N Engl J Med 2003;349:1614-1627.

4 Patterson M, Murphy KG, Thompson EL, Patel S, Ghatei MA, Bloom SR: Administration of kisspeptin-54 into discrete regions of the hypothalamus potently increases plasma luteinising hormone and testosterone in male adult rats. J Neuroendocrinol 2006;18:349354.

$>5$ Plant TM, Ramaswamy S, Dipietro MJ: Repetitive activation of hypothalamic $\mathrm{G}$ proteincoupled receptor 54 with intravenous pulses of kisspeptin in the juvenile monkey (Macaca mulatta) elicits a sustained train of gonadotropin-releasing hormone discharges. Endocrinology 2006;147:1007-1013.

$\checkmark 6$ Seminara SB, Dipietro MJ, Ramaswamy S, Crowley WF Jr, Plant TM: Continuous human metastin 45-54 infusion desensitizes G protein-coupled receptor 54-induced gonadotropin-releasing hormone release monitored indirectly in the juvenile male Rhesus monkey (Macaca mulatta): a finding with therapeutic implications. Endocrinology 2006;147:2122-2126.
-7 Tovar S, Vazquez MJ, Navarro VM, Fernandez-Fernandez R, Castellano JM, Vigo E, Roa J, Casanueva FF, Aguilar E, Pinilla L, Dieguez C, Tena-Sempere M: Effects of single or repeated intravenous administration of kisspeptin upon dynamic LH secretion in conscious male rats. Endocrinology 2006;147: 2696-2704.

$>8$ Caraty A, Smith JT, Lomet D, Ben Said S, Morrissey A, Cognie J, Doughton B, Baril G, Briant C, Clarke IJ: Kisspeptin synchronizes preovulatory surges in cyclical ewes and causes ovulation in seasonally acyclic ewes. Endocrinology 2007;148:5258-5267.

$\checkmark 9$ d'Anglemont de Tassigny X, Fagg LA, Dixon JP, Day K, Leitch HG, Hendrick AG, Zahn D, Franceschini I, Caraty A, Carlton MB, Aparicio SA, Colledge WH: Hypogonadotropic hypogonadism in mice lacking a functional Kiss 1 gene. Proc Natl Acad Sci USA 2007;104: 10714-10719.

10 Ramaswamy S, Seminara SB, Pohl CR, Di Pietro MJ, Crowley WF Jr, Plant TM: Effect of continuous intravenous administration of human metastin 45-54 on the neuroendocrine activity of the hypothalamic-pituitarytesticular axis in the adult male rhesus monkey (Macaca mulatta). Endocrinology 2007; 148:3364-3370

11 Oakley AE, Clifton DK, Steiner RA: Kisspeptin signaling in the brain. Endocr Rev 2009;30:713-743.

-12 Smith JT, Cunningham MJ, Rissman EF, Clifton DK, Steiner RA: Regulation of Kiss 1 gene expression in the brain of the female mouse. Endocrinology 2005;146:3686-3692.

$>13$ Smith JT, Dungan HM, Stoll EA, Gottsch ML, Braun RE, Eacker SM, Clifton DK, Steiner RA: Differential regulation of KiSS-1 mRNA expression by sex steroids in the brain of the male mouse. Endocrinology 2005; 146:29762984.
14 Adachi S, Yamada S, Takatsu Y, Matsui H, Kinoshita M, Takase K, Sugiura H, Ohtaki T, Matsumoto $\mathrm{H}$, Uenoyama Y, Tsukamura $\mathrm{H}$, Inoue $\mathrm{K}$, Maeda K: Involvement of anteroventral periventricular metastin/kisspeptin neurons in estrogen positive feedback action on luteinizing hormone release in female rats. J Reprod Dev 2007;53:367-378.

15 Kauffman AS, Gottsch ML, Roa J, Byquist AC, Crown A, Clifton DK, Hoffman GE, Steiner RA, Tena-Sempere M: Sexual differentiation of Kiss 1 gene expression in the brain of the rat. Endocrinology 2007;148:1774-1783.

$\checkmark 16$ Clarkson J, Herbison AE: Postnatal development of kisspeptin neurons in mouse hypothalamus; sexual dimorphism and projections to gonadotropin-releasing hormone neurons. Endocrinology 2006;147:5817-5825.

17 Clarkson J, d'Anglemont de Tassigny X, Moreno AS, Colledge WH, Herbison AE: Kisspeptin-GPR54 signaling is essential for preovulatory gonadotropin-releasing hormone neuron activation and the luteinizing hormone surge. J Neurosci 2008;28:86918697.

18 Clarkson J, Shamas S, Mallinson S, Herbison AE: Gonadal steroid induction of kisspeptin peptide expression in the rostral periventricular area of the third ventricle during postnatal development in the male mouse. J Neuroendocrinol 2012;24:907-915.

19 Homma T, Sakakibara M, Yamada S, Kinoshita M, Iwata K, Tomikawa J, Kanazawa T, Matsui $\mathrm{H}$, Takatsu Y, Ohtaki T, Matsumoto H, Uenoyama Y, Maeda K, Tsukamura H: Significance of neonatal testicular sex steroids to defeminize anteroventral periventricular kisspeptin neurons and the GnRH/LH surge system in male rats. Biol Reprod 2009;81:12161225.

20 Clarkson J, Boon WC, Simpson ER, Herbison AE: Postnatal development of an estradiolkisspeptin positive feedback mechanism implicated in puberty onset. Endocrinology 2009;150:3214-3220. 
-21 Kim J, Tolson KP, Dhamija S, Kauffman AS: Developmental GnRH signalling is not required for sexual differentiation of kisspeptin neurons but is needed for maximal Kiss 1 gene expression in adult females. Endocrinology 2013;154:3273-3283.

- 22 Mayer C, Acosta-Martinez M, Dubois SL, Wolfe A, Radovick S, Boehm U, Levine JE: Timing and completion of puberty in female mice depend on estrogen receptor alpha-signaling in kisspeptin neurons. Proc Natl Acad Sci USA 2010;107:22693-22698.

23 Brock O, Bakker J: The two kisspeptin neuronal populations are differentially organized and activated by estradiol in mice. Endocrinology 2013;154:2739-2749.

-24 Fiorini Z, Jasoni CL: A novel developmental role for kisspeptin in the growth of gonadotrophin-releasing hormone neurites to the median eminence in the mouse. J Neuroendocrinol 2010;22:1113-1125.

-25 Desroziers E, Droguerre M, Bentsen AH, Robert V, Mikkelsen JD, Caraty A, Tillet Y, Duittoz A, Franceschini I: Embryonic development of kisspeptin neurones in rat. J Neuroendocrinol 2012;24:1284-1295.

-26 Desroziers E, Mikkelsen JD, Duittoz A, Franceschini I: Kisspeptin-immunoreactivity changes in a sex- and hypothalamic-regionspecific manner across rat postnatal development. J Neuroendocrinol 2012;24:1154-1165.

-27 Knoll JG, Clay CM, Bouma GJ, Henion TR, Schwarting GA, Millar RP, Tobet SA: Developmental profile and sexually dimorphic expression of Kiss1 and Kiss1r in the fetal mouse brain. Front Endocrinol (Lausanne) 2013;4: 140.

-28 Takumi K, Iijima N, Ozawa H: Developmental changes in the expression of kisspeptin mRNA in rat hypothalamus. J Mol Neurosci 2011;43:138-145.

-29 Patisaul HB, Todd KL, Mickens JA, Adewale HB: Impact of neonatal exposure to the ERa agonist PPT, bisphenol-A or phytoestrogens on hypothalamic kisspeptin fiber density in male and female rats. Neurotoxicology 2009; 30:350-357.

30 Conte FA, Grumbach MM, Kaplan SL: A diphasic pattern of gonadotropin secretion in patients with the syndrome of gonadal dysgenesis. J Clin Endocrinol Metab 1975;40: 670-674.

- 31 Andrews WW, Advis JP, Ojeda SR: The maturation of estradiol-negative feedback in female rats: evidence that the resetting of the hypothalamic 'gonadostat' does not precede the first preovulatory surge of gonadotropins. Endocrinology 1981;109:2022-2031.

- 32 Gill JC, Wang O, Kakar S, Martinelli E, Carroll RS, Kaiser UB: Reproductive hormonedependent and -independent contributions to developmental changes in kisspeptin in GnRH-deficient hypogonadal mice. PLoS One 2010;5:e11911.
33 Lomniczi A, Loche A, Castellano JM, Ronnekleiv OK, Bosch M, Kaidar G, Knoll JG, Wright H, Pfeifer GP, Ojeda SR: Epigenetic control of female puberty. Nat Neurosci 2013; 16:281-289.

34 Pinilla L, Aguilar E, Dieguez C, Millar RP, Tena-Sempere M: Kisspeptins and reproduction: physiological roles and regulatory mechanisms. Physiol Rev 2012;92:1235-1316.

35 Navarro VM, Castellano JM, McConkey SM, Pineda R, Ruiz-Pino F, Pinilla L, Clifton DK, Tena-Sempere M, Steiner RA: Interactions between kisspeptin and neurokinin $\mathrm{B}$ in the control of GnRH secretion in the female rat. Am J Physiol Endocrinol Metab 2011; 300:E202-E210.

36 Smith JT, Acohido BV, Clifton DK, Steiner RA: KiSS-1 neurones are direct targets for leptin in the $o b / o b$ mouse. J Neuroendocrinol 2006;18:298-303.

- 37 Araujo-Lopes R, Crampton JR, Aquino NS, Miranda RM, Kokay IC, Reis AM, Franci CR, Grattan DR, Szawka RE: Prolactin regulates kisspeptin neurons in the arcuate nucleus to suppress LH secretion in female rats. Endocrinology 2014;155:1010-1020.

38 Qiu X, Dowling AR, Marino JS, Faulkner LD, Bryant B, Bruning JC, Elias CF, Hill JW: Delayed puberty but normal fertility in mice with selective deletion of insulin receptors from Kiss1 cells. Endocrinology 2013;154:13371348.

39 Roa J, Garcia-Galiano D, Varela L, SanchezGarrido MA, Pineda R, Castellano JM, RuizPino F, Romero M, Aguilar E, Lopez M, Gay$\tan$ F, Dieguez C, Pinilla L, Tena-Sempere M: The mammalian target of rapamycin as novel central regulator of puberty onset via modulation of hypothalamic Kiss1 system. Endocrinology 2009; 150:5016-5026.

$\checkmark 40$ Luque RM, Kineman RD, Tena-Sempere M: Regulation of hypothalamic expression of KiSS- 1 and GPR 54 genes by metabolic factors: analyses using mouse models and a cell line. Endocrinology 2007;148:4601-4611.

41 Forbes S, Li XF, Kinsey-Jones J, O’Byrne K: Effects of ghrelin on kisspeptin mRNA expression in the hypothalamic medial preoptic area and pulsatile luteinising hormone secretion in the female rat. Neurosci Lett 2009;460: 143-147.

-42 Atkin SD, Owen BM, Bookout AL, Cravo RM, Lee C, Elias CF, Elmquist JK, Kliewer SA, Mangelsdorf DJ: Nuclear receptor LRH-1 induces the reproductive neuropeptide kisspeptin in the hypothalamus. Mol Endocrinol 2013;27:598-605.

43 Ojeda SR, Lomniczi A, Mastronardi C, Heger S, Roth C, Parent AS, Matagne V, Mungenast AE: Minireview: the neuroendocrine regulation of puberty: is the time ripe for a systems biology approach? Endocrinology 2006;147: 1166-1174
44 d'Anglemont de Tassigny X, Ackroyd KJ, Chatzidaki EE, Colledge WH: Kisspeptin signaling is required for peripheral but not central stimulation of gonadotropin-releasing hormone neurons by NMDA. J Neurosci 2010;30:8581-8590.

45 Shrenker P, Maxson SC: The genetics of hormonal influences on male sexual behavior of mice and rats. Neurosci Biobehav Rev 1983;7: 349-359.

46 De Vries GJ: Sex steroids and sex chromosomes at odds? Endocrinology 2005; 146: 3277-3279.

47 Majdic G, Tobet S: Cooperation of sex chromosomal genes and endocrine influences for hypothalamic sexual differentiation. Front Neuroendocrinol 2011;32:137-145.

48 De Vries GJ, Rissman EF, Simerly RB, Yang LY, Scordalakes EM, Auger CJ, Swain A, Lovell-Badge R, Burgoyne PS, Arnold AP: A model system for study of sex chromosome effects on sexually dimorphic neural and behavioral traits. J Neurosci 2002;22:90059014.

49 Quinn JJ, Hitchcott PK, Umeda EA, Arnold AP, Taylor JR: Sex chromosome complement regulates habit formation. Nat Neurosci 2007; 10:1398-1400.

50 Barker JM, Torregrossa MM, Arnold AP, Taylor JR: Dissociation of genetic and hormonal influences on sex differences in alcoholism-related behaviors. J Neurosci 2010;30: 9140-9144

51 Kuljis DA, Loh DH, Truong D, Vosko AM, Ong ML, McClusky R, Arnold AP, Colwell CS: Gonadal- and sex-chromosome-dependent sex differences in the circadian system. Endocrinology 2013;154:1501-1512.

-52 Budefeld T, Grgurevic N, Tobet SA, Majdic G: Sex differences in brain developing in the presence or absence of gonads. Dev Neurobiol 2008;68:981-995.

53 Grgurevic N, Budefeld T, Spanic T, Tobet SA, Majdic G: Evidence that sex chromosome genes affect sexual differentiation of female sexual behavior. Horm Behav 2012;61:719724.

54 Luo X, Ikeda Y, Parker KL: A cell-specific nuclear receptor is essential for adrenal and gonadal development and sexual differentiation. Cell 1994;77:481-490.

55 Budefeld T, Jezek D, Rozman D, Majdic G: Initiation of steroidogenesis precedes expression of cholesterologenic enzymes in the fetal mouse testes. Anat Histol Embryol 2009;38: 461-466.

56 Ingraham HA, Lala DS, Ikeda Y, Luo X, Shen WH, Nachtigal MW, Abbud R, Nilson JH, Parker KL: The nuclear receptor steroidogenic factor 1 acts at multiple levels of the reproductive axis. Genes Dev 1994;8:2302-2312.

57 Majdic G, Young M, Gomez-Sanchez E, Anderson P, Szczepaniak LS, Dobbins RL, McGarry JD, Parker KL: Knockout mice lacking steroidogenic factor 1 are a novel genetic model of hypothalamic obesity. Endocrinology 2002;143:607-614. 
58 Bodo C, Rissman EF: Androgen receptor is essential for sexual differentiation of responses to olfactory cues in mice. Eur J Neurosci 2007; 25:2182-2190.

59 Paxinos G, Franklin KBJ: The Mouse Brain in the Stereotaxic Coordinates, ed 2. San Diego, Academic Press, 2001.

60 Han SK, Gottsch ML, Lee KJ, Popa SM, Smith JT, Jakawich SK, Clifton DK, Steiner RA, Herbison AE: Activation of gonadotropin-releasing hormone neurons by kisspeptin as a neuroendocrine switch for the onset of puberty. J Neurosci 2005;25:11349-11356.
61 Semaan SJ, Kauffman AS: Daily successive changes in reproductive gene expression and neuronal activation in the brains of pubertal female mice. Mol Cell Endocrinol 2015;401: 84-97.

62 Gerall AA, Dunlap JL: Evidence that the ovaries of the neonatal rat secrete active substances. J Endocrinol 1971;50:529-530.

63 Dunlap JL, Gerall AA, Carlton SF: Evaluation of prenatal androgen and ovarian secretions on receptivity in female and male rats. J Comp Physiol Psychol 1978;92:280-288.
64 Gore AC, Walker DM, Zama AM, Armenti AE, Uzumcu M: Early life exposure to endocrine-disrupting chemicals causes lifelong molecular reprogramming of the hypothalamus and premature reproductive aging. Mol Endocrinol 2011;25:2157-2168.

65 Kauffman AS, Navarro VM, Kim J, Clifton DK, Steiner RA: Sex differences in the regulation of Kiss1/NKB neurons in juvenile mice: implications for the timing of puberty. Am J Physiol Endocrinol Metab 2009;297:E1212E1221.

-66 Bentsen AH, Ansel L, Simonneaux V, TenaSempere M, Juul A, Mikkelsen JD: Maturation of kisspeptinergic neurons coincides with puberty onset in male rats. Peptides 2010;31:275-283. 